\title{
MORO MUSLIMS IN SOUTHERN PHILLIPPINES: The Rise of Abu Sayyaf and the Genealogy of Conflict In Southeast Asia
}

\author{
Herdi Sahrasad ${ }^{1}$, Adhe Nuansa Wibisono ${ }^{2}$, Al Chaidar ${ }^{3}$ \\ ${ }^{1}$ University of Paramadina, Jakarta; Universitas Muhammadiyah \\ Jakarta. ${ }^{2}$ University of Al Azhar, Jakarta; PhD student at Ankara \\ Üniversity, Tomer, Turkey. ${ }^{3}$ University of Malikussaleh Aceh \\ Corresponding Email: sahrasad@yahoo.com
}

\begin{abstract}
The main problem of Moro Muslims in Southern Philippines are now the right to self-determination but it also include poverty, underdevelopment, low education, unemployment, discrimination, and violent conflict. Upon the Spanish colonization for more than three centuries (1521-1898), the Moros were controlled by the United States for almost five decades (1898-1942). Japan colonised them for three years before they were integrated to the Republic of Philippines in 1946. Their struggle for independence still continues today represented by the Moro National Liberation Front (MNLF), establihsed in the late 1960s and led by Nur Misuari, and by the Moro Islamic Liberation Front (MILF) led by Salamat Hasyim in 1981. The birth of the MILF w as a response to dissatisfaction with the MNLF that was considered less assertive in fighting for Bangsamoro's rights and too accommodative to the Philippine government. In early 1990s, Abu Sayyaf Group (ASG) led by Abdulrajak Janjalani emerged to respond the situation. In later development, it rises to become a prominent group involved in a long-standing conflict and terror in this landmark of Southeast Asia region.
\end{abstract}

Keywords: Moro Muslims, Terrorist, Abu Sayyaf, MILF, MNLF, Southern Philippines. Southeast Asia.

DOI: https://doi.org/10.20414/ujis.v22i2.340

\section{Introduction}

MORO MUSLIMS in southern Philippines have experienced conflict and warfare from the colonial era to the present. ${ }^{1}$ Academicians

${ }^{1}$ This paper is part of our research to the field in the Southern Philippines in 
and researchers have noted that the Muslim Moro struggle for independent from foreign colonialization had a little success. Even, under the post-colonial Philippines administration, their struggle have not yet achieved optimal outcomes. As the struggle continues, this gives tremendous impact on the stability in this region and in Southeast Asia in general.

This article attempts to propose a historical analysis to the history of the Moro Muslims' struggle to gain independence. It analyzes the context in which the struggle emerge and examines the leadership, structure of movement and activism behind the independent movement. Specifically, it explores the genealogy of continuous conflict that has been happening in the southern part of the Philippines.

The root of terrorism in the Philippines can only be fully understood in the context of the Bangsamoro problem. Soliman M. Santos gave an explanation of the Bangsamoro problem in which the Abu Sayyaf group found the root of its identity there, namely: the problem of historical and systematic marginalization in their own homeland in the Mindanao islands. ${ }^{2}$ This independence signifies Philippine nationality and statehood but ironically also causes the loss of Moro independence and nationality because the Moro homeland was also incorporated into Philippine territory. ${ }^{3}$

This study shows that the Moro's colonialism by European, American and Japanese and their struggle with the central government of the Philippines after being integrated to it in the

2017-18. The Philippines is an archipelago with 7,107 islands, with a population of a round 60 million, using 87 diffe rent language dialects that reflect the number of ethnic groups and communities. Muslims in the Philippines call themselves "Moro". But this name is actually political, because in reality Moro consists of many ethno linguistic groups, for example Maranow, Maquindanau, Tausuq, Somal, Yakan, Ira Nun, Jamampun, Badjao, Kalibugan, Kalagan and Sangil.

${ }^{2}$ Garrett Atkinson, "Abu Sayyaf: The Father of the Swordsman A Review of the Rise of Islamic Insurgency in the Southern Philippines", Perspective Journal of American Security Project, no. March 2012 (March 2012): 4, accessed April 13, 2014, https://www.americanse curityproject.org/wp-content/uploads/2012/03/AbuSayyaf-The-Father-of-the-Swordsman.pdf.

${ }^{3}$ Rommel C. Banlaoi, Al Harakatul Al Islamiyah: Essays on the Abu Sayyaf Group (Quezon City: Philippine Institute for Peace, Violence and Terrorism Research, 2008), 22. See also Atkinson, "Abu Sayyaf," 5. 
post-colonial era has stimulated the rise of various movement seeking independent and resulted in a continuous tension and conflict in the region.

\section{The History of Struggle for Independence}

The Moro's struggle to gain independent began in the sixteenth century. Since the time of Spanish colonialism when they came for the first time in March of 1521, the Moro's effort for a full independence has seemed less successful. The Spanish conquered and dominated the Moros in the southern Philippines. Although they failed to beat Mindanao and Sulu, they still considered both regions part of their territory.

In 1898 the Spanish occupation ended but the subjugation continued under the US through the Treaty of Paris. ${ }^{4}$ Following the fall of the Japanese power in Asia, The Philippines proclaimed itself as an independent country on July 4, 1946, where the Moro were part of this newly-born nation-state. The uneasy-relationship continue between the central government and the Moros upon independence.

In the reign of President Marcos (1965-1986), the initial conflict occurred as a result of killing in Corregidor. At that time, Philippine Muslim volunteers trained in the tactic's guerilla by an official army were killed on the orders of the commander of the troops. This murder was due to the refusal of the Muslims to be sent to Sabah to conduct military infiltration.

Moro Muslim disappointment against internal colonialism and oppression in the country, led to the birth of Moro Islamic Liberation Front (MNLF). The MNLF is a very influential

\footnotetext{
${ }^{4}$ Regarding further referrals for this paper see, James R. Arnold, The Moro War: How America Battled a Muslim Insurgency in the Philippine Jungle, 1902-1913 (Bloomsbury Press, 2011); Aijaz Ahmad, "Class and Colony in Mindanao," Southeast Asia Chronicle 1982, no. 82 (n.d.): 4-11; Miriam Coronel Ferrer, ed., The SPCPD (Southern Philippines Council for Peace and Development): A Response to the Controversy (Quezon City: University of the Philippines Center for Integrative and Development Studies, 1997); T. M. Burley, The Philippines: An Economic and Social Geography (London: G. Bell and Sons Ltd, 1973); Michael A. Costello, "The Demography of Mindanao," in Mindanao: Land of Unfulfilled Promise, ed. Mark Turner, R.J. May, and Lulu Respall Turner (Quezon City, Philippines: New Day Publishers, 1992).
} 
movement in the Muslim Moro fighting for freedom. The other two groups are the Moro Islamic Liberation Front (MILF) and Abu Sayyaf, formed in 1989. These groups have a common purpose: establishing an independently Islamic theocratic state in Mindanao, the southern Philippines.

The Philippine Government's policy towards the Muslim Moro changed as Corazon Aquino took a power. She promised autonomy in the south provided that this part remained integrated into the country. The negotiation started but the central government was only able to include Nur Misuari, the leader of the Moro National Liberation Front (MNLF).

In March 1984, Salamat Hashim, who was a former member of the Central Executive of MNLF and Chairman of the Foreign Relations Committee of the MNLF, decided to establish the Moro Islamic Liberation Front (MILF), after seeing no longer any hope to Nur Misuari or reconcile with his faction. This resulted in a big split. One group supported Salamat Hashim, while the other group was still loyal to Nur Misuari. At its peak, a group that supported Salamat Hashim in March 1984 formally established its own movement using Islam as an identity marker. From this time, there was deflation of MNLF force. For comparison, the MNLF until 2012 was estimated to have only about 15,000 personnel.

MILF has now become the greatest military power, the strongest movement within the Muslim Moro community whose members reach nearly 60,000 members from across the Muslim province. Furthermore, the policy of The Philippines changed upon the rising of Fidel Ramos as president in 1992. President Ramos provided an opportunity for Nur Misuari to rebuild their relationships and restored the government's image amongst the Moro. Ramos had a program to establish the Philippines as economic tigers among neighbors. For that reason, President Ramos approached Nur Misuari, whom he considered as an effective counterpart to deal with conflicts in south Philippines.

\section{The Emergence of Abu Sayyaf and Its Violent Acts}

In the context of upheaval in southern Philippines, the Abu Sayyaf group firstly appeared in 1989 under the leadership of Abdurajak Janjalani. Abdurajak Janjalani is very aware that the 
factors of history, religion, economy, conditions socio-politics that contributed to the rejection of Muslim groups against state authority and power in the Philippines. For centuries, Moro national identity has been appointed as a unifying Muslim resistance to Christian power, and demands the existence of an autonomous Islamic state. This is one of the effects of colonial power attempts to categorize several Muslim ethno-linguistic groups in the Southern Philippines into one "Bangsamoro" identity.

The motivation of Abdurajak Janjalani behind the formation of the Abu Sayyaf group can be seen as an effort to seek justice and freedom, for all Moro Muslim minorities in the southern Philippines. According to Janjalani, Jihad Fi-Sabilillah, which translates to jihadism, is the noblest form in the struggle in the way of God.

The main objective of the Abu Sayyaf group is to establish a free country that adopts Islamic sharia laws as the basis of moral authority from the laws of the country, and then the sharia law is implemented and obeyed by citizens of the country. Rommel Banlaoi then gave an explanation of the "Four Basic Truths" published by Abdurajak Janjalani in 1993-1994 as a basic guide for the Abu Sayyaf group.

Janjalani studied at the University of Ummul Qura in Mecca for three years and returned to Basilan and Zamboanga, The Philippines to start preaching Islam in $1984 .{ }^{5}$ In 1987 Janjalani visited Libya and worked with Mujahiddin to wage war against the Soviets for several years in Afghanistan. The Abu Sayyaf had a relationship with an Islamic fundamentalist movement, Al-Islamic Tabligh, in 1980. The group under the leadership of Janjalani envisioned the establishment of a state of the Islamic Theocratic State of Mindanao (MIS) and spreads Islam through Jihad.

Abu Sayyaf is a radical movement that often use violence to gain their ends. They were involved in various violent acts in the country. The Abu Sayyaf, also known as Al Harakat Al Islamiyya,

5 Zachary Abuza, Balik-Terrorism: The Return of the Abu Sayyaf (Strategic Studies Institute, 2005), 2, accessed April 13, 2014, http://www.strate gicstudie sinstitute.army.mil/pdffiles/pub625.pdf. 
is a separatist group consisting of Islamic militants based on the southern islands of the Philippines such as Jolo, Basilan and Mindanao.

It was reported that recently they were expanding their network to Malaysia, Thailand and Indonesia. The group is suspected of being responsible for bombings, killings, kidnappings and extortion in an effort to establish a Muslim state in the west of Mindanao and the Sulu Archipelago and create a conducive atmosphere for the creation of a Pan-Islamic big country in the Malay Peninsula (Indonesia and Malaysia) in Southeast Asia.

In 1987, Abdurajak Janjalani traveled to Libya and then joined the Mujahideen and fought the Soviet Union for several years in Afghanistan. In Peswahar, Pakistan, he was expected to meet with Mujahideen funders from Saudi Arabia, Osama bin Laden. Abdulrajak Janjalani then conducted military training in the late 1980s at a military training camp in Khost, Afghanistan, led by a military commander of the Mujahideen from the Ittihad al Islamy faction, Abdur Rab Rasul Sayyaf. The name of the group "Abu Sayyaf" itself is probably taken from that name to honor the Mujahideen military commander. Abdur Rab Rasul Sayyaf is a mentor of Indonesian jihadist Riduan Ishamuddin, known as Hambali, the leader of Jamaa Islamiya. Zachary Abuza stated that Abdurajak Janjalani was one of 48 people of the Executive Council of the Islamic International Brigade. They are responsible to form Al Qaeda's international network. ${ }^{6}$

In 1989, Abdurajak Janjalani recruited members of the Moro National Liberation Front (MNLF) who was dissatisfied Nur Misuari's leadership. These MNLF exponents, including Wahab Akbar, Amilhussin Jumaani and Abdul Ashmad, decided to join Janjalani and the Abu Sayyaf group.

According to Abuza, the Philippine Intelligence assumed that the purpose of forming the Abu Sayyaf group was to intervene and sabotage the ongoing peace process between the Philippine government and the MNLF. Southeast Asia was considered increasingly radical site and became the hub of terrorism. The administration of George W. Bush once stated that Southeast Asia

${ }^{6}$ Ibid. 
was the "second front" in the "war on terror". ${ }^{7}$ One of the causes relate to the birth of a network of radical groups, Al Qaeda, represented by the existence of the Jemaah Islamiyah (JI). This group aims to establish Islamic state in the Southeast Asia region, covering Indonesia, Malaysia, Singapore, Brunei and the Philippines. Similar to the Al Qaeda group, the JI group was also transnational that has mantiqi (branches) in many countries. Due to the character of the MILF's resistance to fighting for independence in south Mindanao, the Philippine government adopted a strong military approach. In the 1990s, the MILF launched a series of armed attacks in southern Philippines, which resulted in retaliation for military attacks from the Philippine army.

In a political context like this, $\mathrm{Al}$ Qaeda is considered to have provided ideological, financial and operational support for networks of radical groups such as MILF and the Abu Sayyaf Group (ASG) in the Philippines, Jemaa Salafiyya (JS) in Thailand, Jemaa Islamiya (JI) and Laskar Jundullah in Indonesia, Collection of Malaysian Mujahidin (KMM) in Malaysia, Arakan Rohingya Nationalist Organization (ARNO) and Rohingya Solidarity Organization (RSO) in Myanmar and Bangladesh. ${ }^{8}$

In addition to military training camps in Afghanistan, $\mathrm{Al}$ Qaeda also sent trainers to form or train military training camps in Asia, Africa and the Middle East. At present many small military camps have sprung up in a number of conflict areas in the region as retaliation for the control of Afghanistan by the United States.

Al Qaeda has succeeded in influencing the political objectives of separatist groups and religious groups in Southeast Asia to win battles at the territorial level and then launch universal jihad throughout the world. For example, the Singapore branch of Jemaah Islamiyah, led by Mas Selamat Kastari, had planned to hijack and crash the Aeroflot aircraft from Bangkok, Thailand to Changi International Airport in Singapore. According to Kastari's

7 Adhe Nuansa Wibisono, "ASEAN dan Institusi Kontra Te rorisme di Asia Tenggara," December 24, 2013.

${ }^{8}$ Rohan Gunaratna, Terrorism In Southeast Asia: Threat and Response, Series II (Islamism in Southeast Asia) 1 (Singa pore: Hudson Institute, Center For Eurasian Policy Occasional Research Paper, 2006), 1-7, https://www.hudson.org/content/ researchattachments/atta chment/518/guna ra tna te rrorismsouthe asta sia.pdf. 
statement, the choice to use Russian airlines is to give Moscow lessons on what was done to Muslim brothers in Chechnya. Likewise, attacks in Bali and the Jakarta Marriot Hotel were intended to cause mass deaths of civilians deemed to be the enemy of Islam.

Such tactics were not previously known by the Southeast Asian group, and are clear examples of method used by Al Qaeda. Then the most powerful impact of Al Qaeda's influence on Southeast Asian militant groups is the idea of fighting against "distant enemies" or as Osama bin Laden said "snake head" addressed to the United States. Imam Samudera, a JI member and one of the key planners in the Bali Bombing attack, revealed during his interrogation that Australia was specifically targeted in the Bali attack due to its direct support to the United States. ${ }^{9} \mathrm{Al}$ Qaeda then called for the establishment of the Islamic Front for Jihad world against the Jews and the Crusaders in February 1998, making this resistance front the main coordination route for Islamic resistance groups around the world. The idea of forming a front was then influenced by militant groups in Southeast Asia that adapted $\mathrm{Al}$ Qaeda's military ideology and tactics. The dissemination of the idea of a unifying ideology of Al Qaeda was marked by the establishment of a regional level organization that overshadowed groups in Southeast Asia, namely, the Rhabitah Al Mujahideen [Legion of the Fighters of God] formed by Hambali in 1999.

Some groups such as the Free Aceh Movement (GAM) in Indonesia, rejected to affiliate itself to $\mathrm{Al}$ Qaeda to unite the ethnonationalist resistance movement which they have been stretching into regional organizations with universal goals. A different response was given by the Moro Islamic Liberation Front (MILF), which had agreed to cooperate with Jemaah Islamiyah and $\mathrm{Al}$ Qaeda in carrying out political resistance and alliances with other militant groups in Southeast Asia. ${ }^{10}$

Although after the 9/11 tragedy, the cooperation between the two extremist groups was no longer heard, the Abu Sayyaf

${ }^{9}$ Ibid., 2.

${ }^{10}$ Ibid., 2-3. 
members had good relations with the Al Qaeda affiliated terrorist group in the Philippines. Osama bin Laden's brother-in-law, Muhammad Jamal Khalifa, is alleged to have provided funds to Abu Sayyaf through a money laundering under the guise of the charity he founded, the Islamic Relief International Organization. ${ }^{11}$

Ramzi Yousef, an instructor of bomb assembly training at the Khost camp in Afghanistan, then traveled with Abdurajak Janjalani to The Philippines from December 1991 to May 1992 at the request of Osama bin Laden to provide bomb-making training to Abu Sayyaf members in their military camps in the Basilan archipelago. Then Ramzi Yousef was introduced to the Abu Sayyaf leaders and as a "bin Laden envoy" and he was called by the nickname "the Chemist" or "Chemist" because of his ability in making bombs. ${ }^{12}$ The Abu Sayyaf group was later widely known by the public when their first bombing attack took place in August 1991 which destroyed the M / V Doulos ship, a Christian missionary ship docked in Zamboanga, southern Philippines. ${ }^{13}$

The Philippine and the US governments have tried to tackle acts of terrorism in the Philippines by attacking the Abu Sayyaf headquarters in the Philippines in June 2002 which killed the Abu Sayyaf leader, Abu Sabaya. The Abu Sayyaf then appointed Yasser Igasan as the leader in 2007, although Igasan did not have military capability. Abu Sayyaf has now far left the ideology of Islam which at first they fought for, and became a radical group that committed crimes without a clear political motive.

Following the demise of its leaders Abdurajak Janjalani, the group was divided into different factions, whose activities were further colored by robbery and kidnapping rather than political struggle. In 2000, this group kidnapped 53 people including priests, several teachers and students asking ransom or threatening to kill the hostages. They did the same in the surrounding region ${ }^{14}$ and kept working this strategy. ${ }^{15}$ Terror

${ }^{11}$ Atkinson, "Abu Sayyaf," 4.

12 Abuza, Balik-Terrorism, 3.

${ }^{13}$ Atkinson, "Abu Sayyaf."

14 Agence France-Presse, "Abu Sayyaf Extremists Battle Troops in Philippines, Leaving 20 Soldiers Injured," The Guardian, April 11, 2014, sec. World 
actions carried out by the Abu Sayyaf group certainly make this group one of the most dangerous militant groups in Southeast Asia today.

\section{Abu Sayyaf's Leadership, Ideology and Strategy}

The first leader (amir) of the Abu Sayyaf group was its founder Abdurajak Janjalani. He was killed in a police attack in December 1998 and was replaced by his younger brother Khadafy Janjalani (Abu Mochtar). Following this, a number of main figures in this group took over the leaderships, such as a former Abu Sayyaf spokesman, Aldam Tilao (Abu Sabaya) and its commander Ghalib Andang. The death of Khadafy Janjalani and his lieutenant Jainal Antel Sali, Jr. (Abu Solaiman) in September 2006 and January 2007 ushered in a new era of leadership for the Abu Sayyaf group. The leadership position was later successfully reunited with one command under the Sulu Abu Sayyaf commander, the commander Radullan Sahiron (Commander of Putol), who was reportedly nearly killed by Filipino marines in Sulu in December $2008 .^{16}$

The structural pattern of the Abu Sayyaf group consists of two main organizational branches, each with its own local commanders both in Sulu and Basilan. The main leadership is now located in Sulu. The new generation of militants seems to have begun taking over leadership of the Abu Sayyaf.

The changing leadership had given a huge impact on its strategy. A security report by The Philippine government reveals that Albader Parad and Sulaiman Pattah in Sulu, then Nurhassan

news, accessed April 13, 2014, https://www.theguardian.com/world/2014/ apr/11/abu-sayyaf-extremists-battle-troops-philippines.

15 Roel Pareño, "Abu Sayyaf Abducts School Principal in Sumisip," Philstar.com, last modified March 31, 2014, accessed April 15, 2014, https://www.philstar.com/nation/2014/03/31/1307219/updated-abu-sayyafabducts-school-principal-sumisip.

16 Soliman M. Santos et al., "Al- Harakatul Al-Islamiyya, Aka Abu Sayyaf Group (ASG)," in Primed And Purposeful Armed Groups And Human Security Efforts In The Philippines, ed. Diana Rodriguez (South-South Network for Non-State Armed Group Engagement and the Small Arms Survey, 2010), 356, accessed April 13, 2014, http://www.isn.ethz.ch/Digital Library/Publications/ Detail/?ots591=0c54e3b3-1e9c-be1e-2c24- a 6a 8c7060233\&lng=en\&id=115743. 
Jamiri and Furuji Indama in Basilan, are the new leaders. Albader Parad is a strong proponent of Ghalib Andang's commander, who is more inclined to lead this group like a criminal group rather than a separatist organization. ${ }^{17}$

The Abu Sayyaf Group operates around the Basilan island province and the Sulu archipelago, as well as three provinces on the Zamboanga peninsula in the western region of Mindanao. This area is generally a rural area. The other area of their base movement includes the Sampinit complex in Upper Kapayoan, in the Basilan district of Isabela, where the Abu Sayyaf group once had a permanent base including the Al-Madinah military camp. In addition, there is also a group base in Punoh Muhaji in the central area of Basilan, where the Abu Sayyaf group once had a base called the Abdurajak military camp.

There was also the headquarter occupied by Radullan Sahiron in the town of Patikul while the headquarter occupied by Doctor Abu was located at the Karawan Complex on the border of the town of Indanan-Parang Maimbung, and the headquarters of the Robot Commander was based in Talipao city. The leadership of the Abu Sayyaf group is estimated to be divided and fragmented, especially after the death of several key leaders during the 20062007 period. At present it is not known for certain whether there is a single leadership within the Abu Sayyaf. Below is the list of person who used to be leaders of this group.

Abdurajak Janjalani (Abu Sayyaf), founder and first leader of the Abu Sayyaf group. He received military training camps in Afghanistan and was killed during a military attack by the Philippines in December 1998. Khadafy Janjalani, the younger brother of Abdurajak Janjalani, became the second leader of the Abu Sayyaf group after the death of Abdurajak Janjalani in 1998. Khadafy Janjalani was later killed in a battle with the Philippine military in the Jolo islands in December 2006.

Aldam Tilao (Abu Sabaya), spokesman and military leader of the Basilan faction of the Abu Sayyaf group, led the group following the death of the first and second leaders. Abu Sabaya was later killed in a military attack in Zamboanga in June 2002.

17 Ibid., 366. 
He was replaced by Galib Andang (Robot Commander), the military leader of the Sulu faction Abu Sayyaf group. When Andang was later killed in a riot in Manila prison in 2005,18 he was replaced by Radullan Sahiron (Putol Commander), a veteran fighter from the MNLF and MILF, who later became the military commander of the Sulu faction of the Abu Sayyaf. It is under his leadership the factions were reunited.

Following this era, the movement was led by various figures, who used a different method and strategy, including kidnapping and torturing the hostages, both the Philippine citizens or international volunteer workers in the southern part of the country. Yasser Igasan, (Commander of Diang), Isnilon Totoni Hapilon (Abu Musab), Albader Parad, Sulaiman Pattah, one of the Abu Sayyaf military commanders from the Sulu faction, Nurhassan Jamiri, one of the Abu Sayyaf military commanders from the Basilan faction, Furuji Indama, the Abu Sayyaf military commanders from the Basilan faction, Abdul Basit Usman, a bomb assembly expert and senior member of the Abu Sayyaf group, Gumbahali Jumdail (Abu Doctor) Alhamser Limbong (Kosovo Commander) and Abdul Basir Latip are amongst the leading figures.

Terror attacks, bombings and kidnappings constitute their strategy despite low personnel. The strategy has increased media coverage that in turn spur their popularity and propaganda. It also forms economic sabotage of state power and fuel their financial sources from ransom. In the context of member recruitment, the Abu Sayyaf group conducted a recruitment process for young people in Mindanao who are around 20 years old. The youths are themselves and their families victims of the war and uninterrupted conflicts in this area and offered with compensation or money payment to join, even though there is an allegation that the group has no formal method of recruitment, training and

${ }_{18}$ BBC, "Bloody End to Manila Jail Break," BBC News Online, last modified March 15, 2005, accessed April 14, 2014, http://news.bbc.co.uk/2/hi/asiapacific/4349471.stm; Zambo Times News Online, "What a New ASG Leader Could Bring," accessed April 17, 2014, http://www.zambotimes.com/ archives/news/7142-What. 
indoctrination. ${ }^{19}$ Some first generation members of the Abu Sayyaf group are former MNLF combatants, MILF or combatants who have participated in military camps in Afghanistan. Young people who have ideological or criminal tendencies are usually recruited to carry out a specific task in the ad hoc training process that they must complete.

The Abu Sayyaf group since its inception has developed and practiced counter-offensive diversion tactics, in which secondary units attack opposing military forces to distract opponents from the main attack unit. This tactic is useful to avoid direct confrontation with the military, except in positions and circumstances that are forced and threatened. The best evidence of the effectiveness of this technique is the fact that this tactic can keep the Abu Sayyaf group afloat against the onslaught of the Philippine armed forces carrying out military operations in Sulu, involving around 8,000 military personnel with high-tech US military support, which began in August 2006, ${ }^{20}$ although this military operation later succeeded in killing the Abu Sayyaf leader Gaddafi Janjalani and his main military lieutenant Abu Solaiman. ${ }^{21}$

Because the islands in the southern Philippine constitute operational areas of the Abu Sayyaf, they are extensively using speedboats as means of public transportation. The Abu Sayyaf group also reportedly had an "urban terrorist group" consisting of 70 motorbike gangs who carried out killings and kidnappings in the city of Jolo for six months until around August 2006. This kidnapping operation was more targeting urban rich Christians than villagers and foreigners who had been the main target of the abduction. ${ }^{22}$

From 1991-2000, the Abu Sayyaf group was involved in 378 violent acts which included bombings, assaults and killings,

${ }_{19}$ Darwin T. Wee, "Abu Sayyaf Actively Recruiting Young Blood - Police," GMA News Online, last modified June 17, 2008, accessed April 14, 2014, https://www.gmanetwork.com/news/story/101477/news/regions/abu-sayyafactively-recruiting-young-blood-police/.

${ }^{20}$ International Crisis Group, Reports, 2008.

${ }^{21}$ Banlaoi, Al Harakatul Al Islamiyah, 22.

22 Santos et al., “Al-Ha rakatul Al-Isla miyya," 370; International Crisis Group, Reports. 
leaving 288 civilians death. Although Khadafy Janjalani was located in the Basilan region, he was controlled by Abu Sabaya (Aldam Tilao) who adopted the same strategy of violence. With the emergence of these two factions, the Abu Sayyaf group underwent a phase of degeneration which made it like a criminal organization. Ghalib Andang and Abu Sabaya transformed the Abu Sayyaf group from a religious-freedom organization into what is referred to as "entrepreneur of violence". ${ }^{23}$

According to the Philippine anti-terrorism unit, the AntiTerrorism Task Force (ATTF), the strength of the Abu Sayyaf group's personnel in 2005 was estimated to be around 350 people. But then the Philippine military, Armed Forces of Philippines (AFP), on an assessment in the second quarter of 2008 stated that the strength of the Abu Sayyaf group amounted to around 380 people. When compared with the strength of the personnel of the New People's Army (NPA) which amounted to 8.000 people and the strength of personnel of the Moro Islamic Liberation Front (MILF) with 10,000 personnel, of course the strength of the Abu Sayyaf group is small. ${ }^{24}$

The factionalization and internal conflicts that occurred with the Abu Sayyaf group were quickly exploited by the Philippine military. By conducting intensive military operations, the Philippine government was able to reduce the strength of the Abu Sayyaf group by $70 \%$. From around 1,269 fighters in 2000, they were reduced to only around 350 personnel in mid-2005..$^{25}$ Other data suggest that in the early 1990s, it was estimated that the Abu Sayyaf group had a membership of 650 people, and at the moment of the Sipadan hostage crisis in 2000, the Abu Sayyaf was believed to grow with a total of 3,000 militants (Torres, 2001). A military brigade commander who was involved in fighting in February 2005 on Jolo Island estimated that there were about $300 \mathrm{Abu}$ Sayyaf combatants on the island (Pajarito 2005). Other figures that correspond to intelligence estimates and the Defense Department mention the numbers this group reached around 409 and 500

\footnotetext{
${ }^{23}$ Banlaoi, Al Harakatul Al Islamiyah, 25.

${ }^{24}$ Ibid., 15.

${ }^{25}$ Ibid., 25.
} 
people. ${ }^{26} \mathrm{~A}$ former commander of the Abu Sayyaf group in Sulu said that the group had 650 regular armed personnel and thousands of others as reserve personnel. ${ }^{27}$

\section{Conclusion}

From the explanation above, it can be concluded that the Abu Sayyaf movement in southern Philippines have an impact on the Southeast Asia region. This movement is historically closely related to the context of colonialism and regional, socio-cultural and political issues. Religion and ethnic identity coincide with each other in within this issue even have an important role in the long tension and violent conflict.

The conflict began with the competition of the Islamic and Christian post-13th century mission. State oppression against Muslim minority groups asking independence became more pronounced when the authorities called them Moro who had a pejorative connotation, meaning that they were identical with Islamic groups that had been invaded and defeated by Spain. Struggle using various means and strategies were thus taken by the Moro and their movement groups such as the MNLF and the previous MILF and the Abu Sayyaf to respond such conditions.

\section{References}

Abuza, Zachary. Balik-Terrorism : The Return of the Abu Sayyaf. Strategic Studies Institute, 2005. Accessed April 13, 2014. http://www.strategicstudiesinstitute.army.mil/pdffiles/pub625 .pdf.

Ahmad, Aijaz. "Class and Colony in Mindanao." Southeast Asia Chronicle 1982, no. 82 (n.d.): 4-11.

Arnold, James R. The Moro War: How America Battled a Muslim Insurgency in the Philippine Jungle, 1902-1913. Bloomsbury Press, 2011.

Atkinson, Garrett. "Abu Sayyaf: The Father of the Swordsman A Review of the Rise of Islamic Insurgency in the Southern Philippines"." Perspective Journal of American Security Project,

${ }^{26}$ Ibid., 22.

27 Santos et al., "Al-Haraka tul Al-Islamiyya," 368. 
no. March 2012 (March 2012): 1-8. Accessed April 13, 2014. https://www.americansecurityproject.org/wpcontent/uploads/2012/03/Abu-Sayyaf-The-Father-of-theSwordsman.pdf.

Banlaoi, Rommel C. Al Harakatul Al Islamiyah: Essays on the Abu Sayyaf Group. Quezon City: Philippine Institute for Peace, Violence and Terrorism Research, 2008.

BBC. "Bloody End to Manila Jail Break." BBC Newa Online. Last modified March 15, 2005. Accessed April 14, 2014. http://news.bbc.co.uk/2/hi/asia-pacific/4349471.stm.

Burley, T. M. The Philippines: An Economic and Social Geography. London: G. Bell and Sons Ltd, 1973.

Costello, Michael A. "The Demography of Mindanao." In Mindanao: Land of Unfulfilled Promise, edited by Mark Turner, R.J. May, and Lulu Respall Turner. Quezon City, Philippines: New Day Publishers, 1992.

Ferrer, Miriam Coronel, ed. The SPCPD (Southern Philippines Council for Peace and Development): A Response to the Controversy. Quezon City: University of the Philippines Center for Integrative and Development Studies, 1997.

France-Presse, Agence. "Abu Sayyaf Extremists Battle Troops in Philippines, Leaving 20 Soldiers Injured." The Guardian, April 11, 2014, sec. World news. Accessed April 13, 2014. https://www.theguardian.com/world/2014/apr/11/abu-sayyafextremists-battle-troops-philippines.

Gunaratna, Rohan. Terrorism In Southeast Asia: Threat and Response. Series II (Islamism in Southeast Asia) 1. Singapore: Hudson Institute, Center For Eurasian Policy Occasional Research Paper, 2006. https://www.hudson.org/content/research attachments/attachment/518/gunaratnaterrorismsoutheastasia. pdf.

International Crisis Group. Reports, 2008.

Pareño, Roel. "Abu Sayyaf Abducts School Principal in Sumisip." Philstar.com. Last modified March 31, 2014. Accessed April 15, 2014.

https://www.philstar.com/nation/2014/03/31/1307219/updatedabu-sayyaf-abducts-school-principal-sumisip. 
Santos, Soliman M., Paz Verdades M. Santos, Octavio A. Dinampo, Herman Joseph S. Kraft, Artha Kira R. Paredes, and Raymund Jose G. Quilop. "Al- Harakatul Al-Islamiyya, Aka Abu Sayyaf Group (ASG)." In Primed And Purposeful Armed Groups And Human Security Efforts In The Philippines, edited by Diana Rodriguez, 364-379. South-South Network for Non-State Armed Group Engagement and the Small Arms Survey, 2010. Accessed April 13, 2014. http://www.isn.ethz.ch/Digital Library/Publications/Detail/?ots591=0c54e3b3-1e9c-be1e-2c24a6a8c7060233\&lng=en\&id=115743.

Wee, Darwin T. "Abu Sayyaf Actively Recruiting Young Blood Police." GMA News Online. Last modified June 17, 2008. Accessed April 14, 2014. https://www.gmanetwork.com/ news/story/101477/news/regions/abu-sayyaf-activelyrecruiting-young-blood-police/.

Wibisono, Adhe Nuansa. "ASEAN dan Institusi Kontra Terorisme di Asia Tenggara." Paper presented at the Kajian Terorisme dan Keamanan Internasional UI, December 24, 2013.

Zambo Times News Online. "What a New ASG Leader Could Bring." Accessed April 17, 2014.http://www.zambotimes.com/ archives/news/7142-What. 